\title{
Determination of the Exergy of Four Wheat Straws
}

\author{
${ }^{1,2}$ Yaning Zhang, ${ }^{2}$ A.E. Ghaly and ${ }^{1}$ Bingxi Li \\ ${ }^{1}$ School of Energy Science and Engineering, Harbin Institute of Technology, Harbin, China \\ ${ }^{2}$ Department of Process Engineering and Applied Science, Faculty of Engineering, \\ Dalhousie University, Halifax, Canada
}

Received 2013-07-27, Revised 2013-08-15; Accepted 2013-09-01

\begin{abstract}
Exergy is a measurement of how far a certain material deviates from a state of equilibrium with the environment. It is a useful tool for improving the efficiency of energy-resource use. The exergy values of four wheat straws (Absolvant, Max, Monopol and Vuka) were determined in this study. The effects of physical and chemical properties (moisture content, ash content, LHV and S, C, O, H and N contents) were evaluated. The moisture related exergy varied from $281.834 \mathrm{~kJ} \mathrm{~kg}^{-1}$ (Monopol) to $366.766 \mathrm{~kJ} \mathrm{~kg}^{-1}$ (Absolvant), accounting for 1.311-1.734\% of the total exergy of wheat straws. A negative linear relationship between the exergy value and moisture content was observed. The ash related exergy varied from $53.468 \mathrm{~kJ} \mathrm{~kg}^{-1}$ (Absolvant) to $117.675 \mathrm{~kJ} \mathrm{~kg}^{-1}$ (Vuka), accounting for $0.253-0.556 \%$ of the total exergy of wheat straws. A negative linear relationship between the exergy value and ash content was observed. The S related exergy ranged from $6.817 \mathrm{~kJ} \mathrm{~kg}^{-1}$ (Max) to $11.077 \mathrm{~kJ} \mathrm{~kg}^{-1}$ (Vuka), accounting for $0.032-0.052 \%$ of the total exergy of wheat straws. A positive linear relationship between the exergy value and $\mathrm{S}$ content was observed. The $\mathrm{O} / \mathrm{C}, \mathrm{H} / \mathrm{C}$ and $\mathrm{N} / \mathrm{C}$ atomic ratios and the correlation factors varied in ranges of $0.7133-0.7537,1.3475-1.5457,0.0063-0.0225$ and $1.133-1.138$, respectively. The exergy values of the four wheat straws were between 21.156 $\mathrm{MJ} \mathrm{kg}^{-1}$ (Absolvant) and 21.503 $\mathrm{MJ} \mathrm{kg}^{-1}$ (Monopol). They were mainly determined by the correlation factors and the LHVs. A positive linear relationship between the exergy value and LHV was observed. The combined contribution of ash, moisture and S related exergy to the total exergy was very small (1.694-2.212\%) and can be neglected.
\end{abstract}

Keywords: Exergy, LHV, Wheat Straw, Moisture, Ash, S, C, O, H, N, Correlation Factor

\section{INTRODUCTION}

Wheat is a staple food for 2.45 billion people $(35$ percent of the world's population) and about 30 million people are engaged in wheat cultivation (Lumpkin, 2011). The global wheat production increased from 589.3 million tonnes in 2001 to 694.5 million tonnes in 2011, about 17.84\% increase (FAO, 2011; Zhang et al., 2012). The cultivation and processing of wheat resulted in about 534.23 million tonnes of wheat straw in 2011 (Zhang et al., 2012).

Wheat straw is currently used as feedstuff (Shrivastava et al., 2012), a soil conditioner (Xie et al., 2011), in pulp and paper industry (Hedjazi et al., 2009), production of nano-materials (Chen et al., 2010) and production of bioethanol (Talebnia et al., 2010). Wheat straw can also be used as a renewable energy source in thermochemical conversion processes such as pyrolysis (Wild et al., 2012), combustion (Wang et al., 2009) and gasification (Ren et al., 2010).

Although the physical, chemical and thermochemical properties of wheat straws (moisture content, bulk density, particle size, porosity, heating values, proximate analysis, ultimate analysis, ash composition, ash characteristics and degradation kinetics) are well studied (Ghaly and Al-Taweel, 1990; Natarajan et al., 1998; Guo et al., 2012; Igathinathane et al., 2010; Zhang et al.,

Corresponding Author: A.E. Ghaly, Department of Process Engineering and Applied Science, Faculty of Engineering, Dalhousie University, Halifax, Canada Email: abdel.ghaly@dal.ca 
2012), no detailed analysis of the exergy of wheat straw has been reported. The main objectives of this study were: (a) to determine the exergy values of four different wheat straws and (b) to determine the effects of some physical and chemical properties (moisture content, ash content, $\mathrm{S}, \mathrm{C}, \mathrm{O}, \mathrm{H}$ and $\mathrm{N}$ contents) on the exergy values of wheat straws.

\section{EXERGY ANALYSIS OF BIOMASS FUELS}

Exergy is the amount of work obtainable when a matter is brought to a state of thermodynamic equilibrium with the common components of the natural surroundings such as environmental condition by means of reversible processes, involving interaction only with the components of natural surroundings (Szargut, 1980). It is a measurement of how far a certain system deviates from a state of equilibrium with its environment (Wall, 1986). Unlike energy, exergy is not subject to conservation law (except for ideal or reversible processes). It is consumed or destroyed due to unavoidable irreversibilities in any real process.

Exergy analysis is a methodology that uses the conservation of energy principle (embodied in the first law of thermodynamics) together with non-conservation of entropy principle (embodied in the second law) for the analysis, design and improvement of energy systems (Rosen and Bulucea, 2009; Dincer, 2002). The exergy method is useful for improving the efficiency of energy-resource use. It quantifies the locations, types and magnitudes of wastes and losses. In general, more meaningful efficiencies can be evaluated with exergy analysis rather than energy analysis, since exergy efficiencies are always a measure of the approach to the ideal condition (Rosen and Bulucea, 2009).

The exergy of a material can be calculated from its chemical potential and concentrations in its actual state and reference state (Wall, 1986). For irregular materials such as biomass fuels with unknown chemical potential, the exergy values can be obtained as follows (Szargut et al., 1988):

$$
e x=\beta\left(\mathrm{LHV}+\eta_{\mathrm{w}} h_{\mathrm{w}}\right)+9683 \eta_{\mathrm{s}}+e x_{\mathrm{ash}} \eta_{\mathrm{ash}}+e x_{\mathrm{w}} \eta_{\mathrm{w}}
$$

where:

ex $\quad=$ The exergy of the fuels $\left(\mathrm{kJ} \mathrm{kg}^{-1}\right)$

$\beta \quad=$ The correlation factor

$h_{\mathrm{w}}=$ The evaporation enthalpy of moisture $\left(\mathrm{kJ} \mathrm{kg}^{-1}\right)$

$\eta_{\mathrm{w}} \quad=$ The moisture content (\%)

$\eta_{\mathrm{s}} \quad=$ The weight percentage of sulfur (\%) $\eta_{\text {ash }}=$ The weight percentage of ash (\%)

$e x_{\text {ash }}=$ The exergy of ash $\left(\mathrm{kJ} \mathrm{kg}^{-1}\right)$

$e x_{\mathrm{w}} \quad=$ The exergy of water $\left(\mathrm{kJ} \mathrm{kmol}^{-1}\right)$

$L H V=$ The lower heating value of biomass fuels $\left(\mathrm{kJ} \mathrm{kg}^{-1}\right)$

The value of $2442 \mathrm{~kJ} \mathrm{~kg}^{-1}$ was reported for the evaporation enthalpy of moisture by Szargut et al. (1988) and the value of $900 \mathrm{~kJ} \mathrm{kmol}^{-1}$ was reported for the exergy of water by Moran et al. (2011). The correlation factors of biomass materials can be obtained through the following equations based on the biomass type and elemental composition (Szargut et al., 1988):

(a) For solid hydrocarbons

$\beta=1.0435+0.0159 \frac{H}{C}$

(b) For solid fuels containing $\mathrm{C}, \mathrm{H}$ and $\mathrm{O}$

$$
\begin{array}{ll}
\beta=1.0438+0.0158 \frac{H}{C}+0.0813 \frac{O}{C} & (\mathrm{O} / \mathrm{C} \leq 0.5) \\
\beta=\frac{1.0414+0.0177 \frac{H}{C}-0.3328 \frac{O}{C}\left(1+0.0537 \frac{H}{C}\right)}{1-0.4021 \frac{O}{C}} \quad(\mathrm{O} / \mathrm{C} \leq 2)
\end{array}
$$

(c) For solid fuels containing C, H, O and N

$$
\begin{aligned}
& \beta=1.0437+0.0140 \frac{H}{C}+0.0968 \frac{O}{C}+0.0467 \frac{N}{C} \quad(\mathrm{O} / \mathrm{C} \leq 0.5)(5) \\
& \beta=\frac{1.044+0.0160 \frac{H}{C}-0.3493 \frac{O}{C}\left(1+0.0531 \frac{H}{C}\right)+0.0493 \frac{N}{C}}{1-0.4124 \frac{O}{C}}
\end{aligned}
$$

(d) For wood:

$$
\beta=\frac{1.0412+0.2160 \frac{\eta_{\mathrm{H}}}{\eta_{\mathrm{C}}}-0.2499 \frac{\eta_{\mathrm{O}}}{\eta_{\mathrm{C}}}\left(1+0.7884 \frac{\eta_{\mathrm{H}}}{\eta_{\mathrm{C}}}\right)+0.0450 \frac{\eta_{\mathrm{N}}}{\eta_{\mathrm{C}}}}{1-0.3035 \frac{\eta_{\mathrm{O}}}{\eta_{\mathrm{C}}}}
$$

where:

$C \quad=$ The number of carbon in the molecular formula of fuel

$H \quad=$ The number of hydrogen in the molecular formula of fuel

$O \quad=$ The number of oxygen in the molecular formula of fuel

$N \quad=$ The number of nitrogen in the molecular formula of fuel

$\eta_{\mathrm{C}} \quad=$ The weight percentage of carbon (\%)

$\eta_{\mathrm{H}} \quad=$ The weight percentage of hydrogen (\%)

$\eta_{\mathrm{O}} \quad=$ The weight percentage of oxygen $(\%)$

$\eta_{\mathrm{N}}=$ The weight percentage of nitrogen (\%) 


\section{MATERIALS AND METHODS}

\subsection{Straw Collection and Preparation}

The four wheat straws used in this study are Absolvant, Max, Monopol and Vuka. The straw samples were obtained from harvested field at a farm located in the Annapolis Valley, Nova Scotia, Canada. Small rectangular bales of $850 \mathrm{~mm} \times 500 \mathrm{~mm} \times 350 \mathrm{~mm}$ as well as loose straw samples of $15 \mathrm{~kg}$ each were brought to the laboratory.

The naturally dried straw samples were coarse ground through a 20 -mesh sieve $(0.85 \mathrm{~mm})$ on a medium size Wiley Mill (Model X876249, Brook Crompton Parkinson Limited, Toronto, Ontario). The coarse ground samples were then reground through a 40-mesh sieve $(0.425 \mathrm{~mm})$ on the Wiley Mill in order to narrow the range of particle size and thus obtain homogeneous samples. The ground straw samples were dried at $105{ }^{\circ} \mathrm{C}$ for 24 hours in a force-air drying oven. The dried samples were then stored in airtight plastic containers.

\subsection{Moisture Content}

Moisture content was determined for the naturally dried straw samples using the oven-drying method E871-82 (ASTM 2006). A large aluminum dish was weighed using a digital balance (Model PM 4600, Mettler Instrument AG, Greifensee, Zurich). The dish was first weighed and a straw sample weighing approximately 1.0 $\mathrm{kg}$ was placed in the dish. The dish and straw sample were then placed in an air-forced drying oven (Heratherm, Thermo Fisher Scientific Inc., Waltham, USA) and kept at $105{ }^{\circ} \mathrm{C}$ until a constant weight was achieved. The dish containing the dried sample was cooled to the room temperature in a desiccator and then weighed. The moisture content was calculated on wet basis.

\subsection{Lower Heating Value}

A bomb calorimeter (Parr Model 1241 Automatic Adiabatic Calorimeter) was used to determine the higher heating values (HHVs) of the straw samples. The higher heating values were determined following the American Society for Testing and Materials Standard Test Method D5865-10a (ASTM 2010). To avoid the sudden release of volatiles and expelling the straw particles from the combustion crucibles which can result in incomplete combustion, the ground samples were made into 0.5-1.0 $\mathrm{g}$ pellets in a moulding die by a hydraulic press of 50 MPa (Parr Instrument Company, Moline, Illinois, USA). The lower heating values (LHVs) of the straws were then calculated (Bilgen et al., 2004).

\subsection{Ash Content and Compositions}

The standard test method for ash in biomass (E1755-01) was followed to determine the ash percentage in the straw sample (ASTM 2007). The ash samples were obtained by ashing the coarse ground straw in porcelain crucibles using muffle furnace (Model F47900, Thermo Fisher Scientific Inc., Asheville, USA) at $600{ }^{\circ} \mathrm{C}$ for one hour at first. The ash samples were cooled in a desiccator and then weighed. The ashing was again performed for one hour and the samples were cooled again in a desiccator and then weighed. This process was repeated until a constant weight was achieved. The ash was stored in airtight plastic containers till send for ash composition analysis. The ash composition analysis was performed at the Mineral Engineering Laboratory of Dalhousie University. During the ash composition analysis, the weight fractions of $\mathrm{SiO}_{2}, \mathrm{~K}_{2} \mathrm{O}, \mathrm{CaO}, \mathrm{P}_{2} \mathrm{O}_{5}, \mathrm{MgO}, \mathrm{Al}_{2} \mathrm{O}_{3}, \mathrm{Fe}_{2} \mathrm{O}_{3}, \mathrm{Na}_{2} \mathrm{O}, \mathrm{SO}_{3}$ and $\mathrm{ZnO}$ were determined. LECO induction furnace method and atomic absorption were used.

\section{5. $\mathrm{C}, \mathrm{O}, \mathrm{H}, \mathrm{N}$ and $\mathrm{S}$ Contents}

The weight fractions of $\mathrm{C}, \mathrm{H}, \mathrm{N}$ and $\mathrm{S}$ of the ground and oven-dried straw samples were determined, and the weight fraction of $\mathrm{O}$ was calculated by the difference. The weight fractions of $\mathrm{C}, \mathrm{H}$ and $\mathrm{N}$ were determined at the Mineral Engineering Laboratory of Dalhousie University using a Perkin-Elmer Model 240 CHN Elemental Analyzer (Perkin Elmer Inc., California, USA). S was determined using the ICP induction coupled plasma-atomic method D6349-09 (ASTM 2009).

\section{RESULTS AND DISCUSSION}

\subsection{Characteristics of Straws}

\subsubsection{Moisture Content}

The moisture contents of the four wheat straws are shown in Table 1. The moisture contents of the four wheat straws varied between $10 \%$ and $13 \%(30 \%$ variation).

Table 1. Moisture contents, LHVs and ash contents of wheat straws.

\begin{tabular}{lccc}
\hline \multicolumn{3}{c}{ Straws. } \\
straw & $\begin{array}{c}\text { Moisture content } \\
(\%)\end{array}$ & $\begin{array}{c}\text { LHV } \\
\left(\mathrm{MJ} \mathrm{kg}^{-1}\right)\end{array}$ & $\begin{array}{c}\text { Ash content } \\
(\%)^{\mathrm{a}}\end{array}$ \\
\hline Absolvant & 13 & 18.31 & 2.69 \\
Max & 12 & 18.38 & 3.19 \\
Monopol & 10 & 18.71 & 3.23 \\
Vuka & 12 & 18.29 & 4.23 \\
\hline
\end{tabular}

${ }^{\mathrm{a}}$ On as received basis. 
The Absolvant wheat straw had the highest moisture content whereas the Monopol wheat straw had the lowest moisture content. These differences may be due to variations in climatic conditions, soil types, cultivation methods and fertilizer types (Zhang et al., 2012).

Liang et al. (2003) and Pommier et al. (2008) stated that high moisture content can increase the biodegradation rate of organic material during storage, resulting in the loss of calorific value of the fuel. High moisture content of wheat straw can also substantially affect its quality as a fuel source (Zhang et al., 2012). Ghaly and Al-Taweel (1990) and Chen et al. (2009) reported that an increase in moisture contents of the fuels caused deterioration and decreased their heating values. A dry material is thus preferred for storage, gasification and combustion (Zhang et al., 2012).

\subsubsection{Lower Heating Value}

Tesfa et al. (2013) stated that LHV is one of the most important physicochemical properties of biofuels. The LHVs of the four wheat straws are shown in Table 1. The LHVs of the four wheat straws varied between 18.29 $\mathrm{MJ} \mathrm{kg}^{-1}$ (Vuka) and $18.71 \mathrm{MJ} \mathrm{kg}^{-1}$ (Monopol), a variation of $2.30 \%$. These values (18.29-18.71 $\left.\mathrm{MJ} \mathrm{kg}^{-1}\right)$ are higher than the value of $15.78 \mathrm{MJ} \mathrm{kg}^{-1}$ reported by Lin et al. (2003) and the value of 13.882-14.275 $\mathrm{MJ} \mathrm{kg}^{-1}$ reported by Wang et al. (2009) for wheat straws. Vargas-Moreno et al. (2012) stated that the LHV of a biomass fuel can be affected by elemental composition, structure and physical properties of biomass.

\subsubsection{Ash Content}

Ash content is an important thermochemical property of an energy resource. The ash contents of the four wheat straws are shown in Table 1. The ash contents of the four wheat straws varied from $2.69 \%$ (Absolvant) to $4.23 \%$ (Vuka), a variation of $57.25 \%$. These values (2.69-4.23\%) are lower than the $8.73-10.1 \%$ reported by Çöpür et al. (2012) for Turkish wheat straws but within the range of 2.06-5.16\% reported by Petrik et al. (2013) for Danish wheat straws.

The ash content affects the property of a fuel as an energy resource. Vargas-Moreno et al. (2012) and Zhao et al. (2012) stated that the ash content of a fuel can reduce its heating value and cause agglomeration. Ghaly and Al-Taweel (1990) stated that the ash content indicates the potential for the formation of undesirable bonded deposits on combustor surfaces. Ergüdenler and Ghaly (1993) reported on the agglomeration of wheat straw in a fluidized bed gasification system. Lower ash content fuels are, therefore, preferred.

\subsubsection{Ash Compositions}

The detailed ash compositions of the four wheat straws are shown in Table 2. All the straw varieties had high contents of $\mathrm{SiO}_{2}\left(0.141-0.214 \mathrm{~mol} \mathrm{~kg}{ }^{-1}\right.$ fuel) and $\mathrm{K}_{2} \mathrm{O}\left(0.073-0.229 \mathrm{~mol} \mathrm{~kg}^{-1}\right.$ fuel) and low content of $\mathrm{ZnO}$ (0.000-0.001 mol kg-1 fuel). The differences in mineral oxide concentrations could be the result of the variations in climatic conditions, soil types, cultivation methods and fertilizer types (Zhang et al., 2012).

Lin et al. (2003) stated that agglomeration and defluidization in a fluidized bed was affected by the ash composition. Liu et al. (2009) stated that the alkali metals such as $\mathrm{K}$ and $\mathrm{Na}$ which exist in the outer layer of straw particles will melt and coat on the surfaces of ash particles, making ash particles sticky and adhere to the surfaces of bed particles.

Table 2. Mineral oxide compositions of wheat straws.

\begin{tabular}{lllllllllll}
\hline Wheat & \multicolumn{8}{c}{ Mineral oxide composition $\left(\times 10^{-3}\right.$ mol per kg of straw $)$} \\
\cline { 2 - 11 } straw & \multicolumn{3}{c}{$\mathrm{SiO}_{2} \mathrm{~K}_{2} \mathrm{O} \mathrm{CaO} \mathrm{P}_{2} \mathrm{O}_{5}$} & $\mathrm{MgO} \mathrm{Al}_{2} \mathrm{O}_{3}$ & $\mathrm{Fe}_{2} \mathrm{O}_{3}$ & $\mathrm{Na}_{2} \mathrm{O} \mathrm{SO}_{3}$ & $\mathrm{ZnO}$ \\
\hline Absolvant & 141 & 73 & 72 & 18 & 35 & 1 & 1 & 7 & 8 & 0 \\
Max & 214 & 81 & 64 & 13 & 43 & 3 & 1 & 4 & 6 & 0 \\
Monopol & 147 & 124 & 62 & 15 & 34 & 2 & 2 & 5 & 10 & 1 \\
Vuka & 188 & 229 & 64 & 16 & 32 & 3 & 2 & 7 & 11 & 1 \\
\hline
\end{tabular}

Table 3. C, H, O, N, and S contents (wt.\%) of wheat straws.

\begin{tabular}{lccccc}
\hline Wheat straw & $\mathrm{C}$ & $\mathrm{H}$ & $\mathrm{O}$ & $\mathrm{N}$ & $\mathrm{S}$ \\
\hline Absolvant & 39.985 & 5.150 & 38.959 & 0.296 & 0.104 \\
Max & 40.515 & 5.069 & 38.535 & 0.730 & 0.070 \\
Monopol & 41.373 & 5.202 & 39.735 & 0.495 & 0.108 \\
Vuka & 38.949 & 4.374 & 39.142 & 1.021 & 0.114 \\
\hline
\end{tabular}

On as received basis.

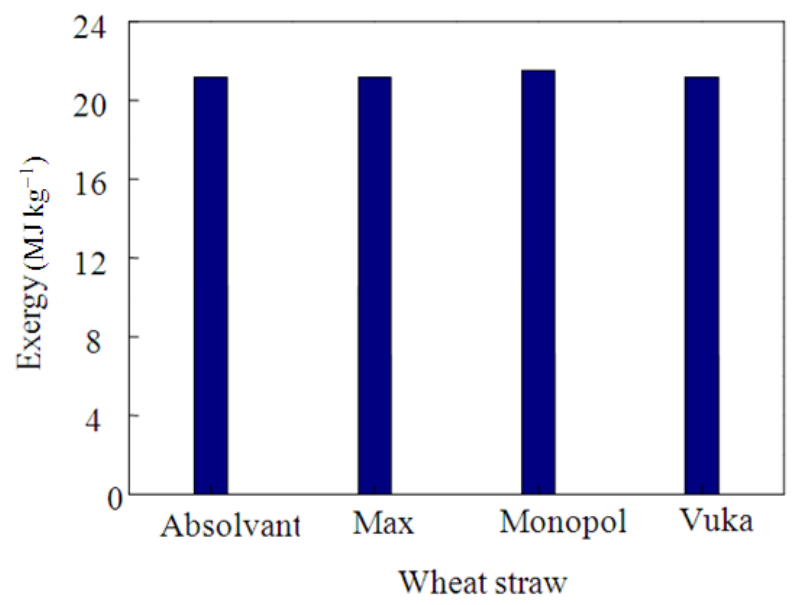

Fig. 1. Exergy values of wheat straws 
The large-sized ash particles may act as the necks in the formation of agglomerates. The small-sized ash particles, however, contribute to the formation of coating layers which is the direct reason for bed defluidization.

\subsubsection{C, O, H, $N$ and S Contents}

Table 3 shows the $\mathrm{C}, \mathrm{H}, \mathrm{O}, \mathrm{N}$ and $\mathrm{S}$ contents of the four wheat straws. Although different straws had different $\mathrm{C}, \mathrm{H}, \mathrm{O}, \mathrm{N}$ and $\mathrm{S}$ contents, all the straws had high contents of $\mathrm{C}(38.949-41.373$ wt.\%) and $\mathrm{O}$ (38.535-39.735 wt.\%) followed by $\mathrm{H}$ (4.374-5.202 wt.\%), N (0.296-1.021 wt.\%) and S (0.070-0.114 wt.\%). Lin et al. (2003) reported the percentages of $48.84 \%$, $7.08 \%, 41.56 \%, 1.28 \%$ and $0.23 \%$ for the $\mathrm{C}, \mathrm{H}, \mathrm{O}, \mathrm{N}$ and $\mathrm{S}$ contents of a wheat straw, respectively. Wen et al. (2013) reported that the $\mathrm{C}, \mathrm{H}, \mathrm{O}, \mathrm{N}$ and $\mathrm{S}$ contents for coal were $53.6-73.7 \%, 3.2-5.4 \%, 3.2-16.7 \%, 0.8-1.0 \%$ and $0.6-1.4 \%$, respectively. The coals have much higher LHVs than wheat straws because of their higher carbon contents.

\subsection{Exergy Values of Wheat Straws}

\subsubsection{Exergy Values}

The exergy values (Fig. 1) were 21.156, 21.171, 21.503 and $21.172 \mathrm{MJ} \mathrm{kg}^{-1}$ for the Absolvant, Max, Monopol and Vuka wheat straws, respectively. These exergy values are within the range of 16.723-21.964 MJ $\mathrm{kg}^{-1}$ reported by Zhang et al. (2011) for biomass fuels.

\subsubsection{Effect of LHV}

The exergy values of straws were determined from their LHVs. The results showed that the higher the LHV the higher the exergy value. The Monopol wheat straw had the highest LHV (18.71 $\mathrm{MJ} \mathrm{kg}^{-1}$ ), and, thus, had the highest exergy (21.503 $\mathrm{MJ} \mathrm{kg}^{-1}$ ).

Bilgen and Kaygusuz (2008) used HHVs to calculate the exergy of coals. Hosseini et al. (2012) and Hepbasli (2008) used LHVs to calculate the exergy of biomass fuels. Zhang et al. (2011) reported the LHVs and exergy of three biomass fuels and found the exergy to be affected by the LHVs of the fuels. In this study, a positive linear relationship between the exergy value and LHV was observed as shown in Fig. 2. The relationship can be described by the following linear equation $\left(\mathrm{R}^{2}=0.945\right)$ :

$\mathrm{Ex}=5.683+0.845 \mathrm{LHV}$

$(18.29 \leq \mathrm{LHV} \leq 18.71)$

The results showed that increasing the LHV from $18.29 \mathrm{MJ} \mathrm{kg}^{-1}$ to $18.71 \mathrm{MJ} \mathrm{kg}^{-1}(2.30 \%)$ increased the exergy of wheat straw from $21.156 \mathrm{MJ} \mathrm{kg}^{-1}$ to $21.503 \mathrm{MJ}$ $\mathrm{kg}^{-1}$ (1.64\%). Similar results were reported by Bilgen et al. (2004) that the exergy value of coal varies proportionally with the heating value.

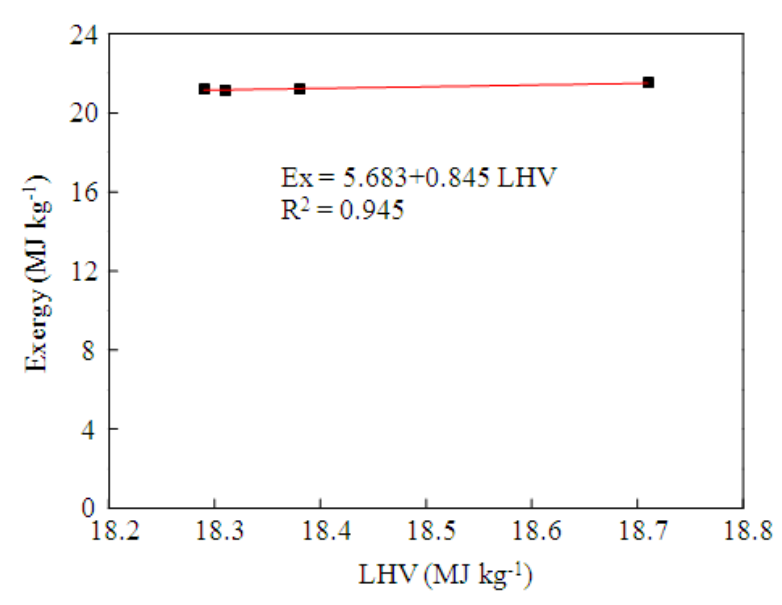

Fig. 2. Relationship between exergy value and LHV

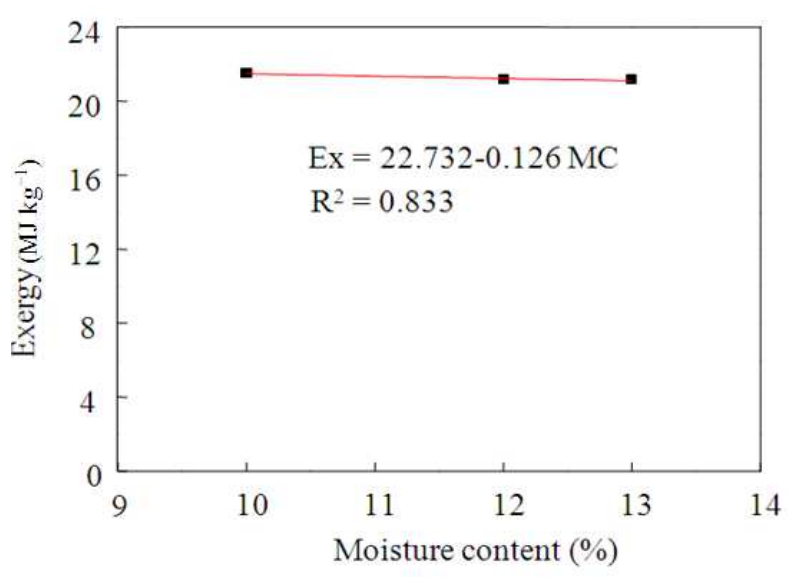

Fig. 3. Relationship between exergy value and moisture

Table 4. Exergy values of mineral oxides (Szargut et al., 1988).

\begin{tabular}{lc}
\hline Mineral oxide & Exergy value $\left(\mathrm{kJ} \mathrm{mol}^{-1}\right)$ \\
\hline $\mathrm{SiO}_{2}$ & 7.90 \\
$\mathrm{~K}_{2} \mathrm{O}$ & 413.10 \\
$\mathrm{CaO}$ & 110.20 \\
$\mathrm{P}_{2} \mathrm{O}_{5}$ & 412.65 \\
$\mathrm{MgO}$ & 66.80 \\
$\mathrm{Al}_{2} \mathrm{O}_{3}$ & 200.40 \\
$\mathrm{Fe}_{2} \mathrm{O}_{3}$ & 16.50 \\
$\mathrm{Na}_{2} \mathrm{O}$ & 296.20 \\
$\mathrm{SO}_{3}$ & 249.10 \\
$\mathrm{ZnO}$ & 22.90 \\
\hline
\end{tabular}

\subsubsection{Effect of Moisture Content}

The moisture related exergy values were 366.766 , $338.038,281.834$ and $339.600 \mathrm{~kJ} \mathrm{~kg}^{-1}$ for the Absolvant, Max, Monopol and Vuka wheat straws, respectively. 
Table 5. Values and fractions of exergy of mineral oxide compositions.

\begin{tabular}{|c|c|c|c|c|c|c|c|c|}
\hline \multirow{3}{*}{$\begin{array}{l}\text { Mineral } \\
\text { oxide }\end{array}$} & \multicolumn{8}{|c|}{ Values and fractions } \\
\hline & \multicolumn{2}{|c|}{ Absolvant } & \multicolumn{2}{|c|}{ Max } & \multicolumn{2}{|c|}{ Monopol } & \multicolumn{2}{|c|}{ Vuka } \\
\hline & $\begin{array}{c}\text { Value } \\
\left(\mathrm{kJ} \mathrm{kg}^{-1}\right)\end{array}$ & $\begin{array}{c}\text { Fraction } \\
(\%)\end{array}$ & $\begin{array}{c}\text { Value } \\
\left(\mathrm{kJ} \mathrm{kg}^{-1}\right)\end{array}$ & $\begin{array}{c}\text { Fraction } \\
(\%)\end{array}$ & $\begin{array}{c}\text { Value } \\
\left(\mathrm{kJ} \mathrm{kg}^{-1}\right)\end{array}$ & $\begin{array}{c}\text { Fraction } \\
(\%)\end{array}$ & $\begin{array}{c}\text { Value } \\
\left(\mathrm{kJ} \mathrm{kg}^{-1}\right)\end{array}$ & $\begin{array}{c}\text { Fraction } \\
(\%)\end{array}$ \\
\hline$\overline{\mathrm{SiO}_{2}}$ & 1.112 & 2.080 & 1.694 & 3.148 & 1.158 & 1.607 & 1.486 & 1.263 \\
\hline $\mathrm{K}_{2} \mathrm{O}$ & 29.979 & 56.070 & 33.437 & 62.127 & 51.220 & 71.075 & 94.720 & 80.493 \\
\hline $\mathrm{CaO}$ & 7.950 & 14.869 & 7.106 & 13.203 & 6.851 & 9.507 & 7.012 & 5.959 \\
\hline $\mathrm{P}_{2} \mathrm{O}_{5}$ & 7.542 & 14.106 & 5.526 & 10.268 & 6.106 & 8.473 & 6.768 & 5.751 \\
\hline $\mathrm{MgO}$ & 2.325 & 4.348 & 2.843 & 5.282 & 2.243 & 3.112 & 2.153 & 1.830 \\
\hline $\mathrm{Al}_{2} \mathrm{O}_{3}$ & 0.285 & 0.533 & 0.678 & 1.260 & 0.464 & 0.644 & 0.524 & 0.445 \\
\hline $\mathrm{Fe}_{2} \mathrm{O}_{3}$ & 0.024 & 0.045 & 0.021 & 0.039 & 0.025 & 0.035 & 0.026 & 0.022 \\
\hline $\mathrm{Na}_{2} \mathrm{O}$ & 2.133 & 3.989 & 1.069 & 1.986 & 1.498 & 2.079 & 2.205 & 1.874 \\
\hline $\mathrm{SO}_{3}$ & 2.108 & 3.943 & 1.441 & 2.677 & 2.483 & 3.446 & 2.766 & 2.351 \\
\hline $\mathrm{ZnO}$ & 0.009 & 0.017 & 0.005 & 0.009 & 0.018 & 0.025 & 0.014 & 0.012 \\
\hline Total & 53.468 & 100.000 & 53.819 & 99.999 & 72.065 & 100.003 & 117.675 & 100.000 \\
\hline
\end{tabular}

The exergy value for water is $900 \mathrm{~kJ} \mathrm{kmol}^{-1}$ (Moran et al., 2011). Therefore, the moisture related exergy values were proportional to the moisture contents of wheat straws. The Absolvant wheat straw had the highest moisture content $(13 \%)$ and highest moisture related exergy (366.766 kJ kg-1) whereas the Monopol wheat straw had the lowest moisture content $(10 \%)$ and the lowest moisture related exergy $\left(281.834 \mathrm{~kJ} \mathrm{~kg}^{-1}\right)$.

In this study, a negative linear relationship between the exergy of wheat straw and moisture content was observed (Fig. 3). The relationship can be described by the following linear equation $\left(\mathrm{R}^{2}=0.833\right)$ :

$\mathrm{Ex}=22.732-0.126 \mathrm{MC}$

$(10 \leq \mathrm{MC} \leq 13)$

where:

MC = The moisture content (\%)

The results showed that increasing the moisture content from $10 \%$ to $13 \%(30 \%)$ decreased the exergy of wheat straw from $21.503 \mathrm{MJ} \mathrm{kg}^{-1}$ to $21.156 \mathrm{MJ} \mathrm{kg}^{-1}$ $(1.61 \%)$. The change in exergy due to changes in moisture content is quite small and the contribution of moisture content to the total exergy of wheat straw is very small and can be neglected. Similar results were reported by Bilgen and Kaygusuz (2008) for coal and Song et al. (2012) for biomass.

\subsubsection{Effect of Ash}

The exergy values of mineral oxides $\left(\mathrm{SiO}_{2}, \mathrm{~K}_{2} \mathrm{O}\right.$, $\mathrm{CaO}, \mathrm{P}_{2} \mathrm{O}_{5}, \mathrm{MgO}, \mathrm{Al}_{2} \mathrm{O}_{3}, \mathrm{Fe}_{2} \mathrm{O}_{3}, \mathrm{Na}_{2} \mathrm{O}, \mathrm{SO}_{3}$ and $\mathrm{ZnO}$ ) are presented in Table 4 . The values and fractions of mineral oxides obtained for different wheat straws are shown in Table 5. For all wheat straws, $\mathrm{K}_{2} \mathrm{O}$ contributed the most $(56.070-80.493 \%)$ to the exergy values of ash, followed by $\mathrm{CaO} \quad(5.959-14.869 \%), \quad \mathrm{P}_{2} \mathrm{O}_{5}$ (5.751-14.106\%), $\mathrm{MgO} \quad(1.830-5.282 \%), \quad \mathrm{Na}_{2} \mathrm{O}$ $(1.874-3.989 \%), \quad \mathrm{SO}_{3} \quad(0.445-1.260 \%), \quad \mathrm{Fe}_{2} \mathrm{O}_{3}$ (0.022-0.045\%) and $\mathrm{ZnO}(0.009-0.025 \%)$.

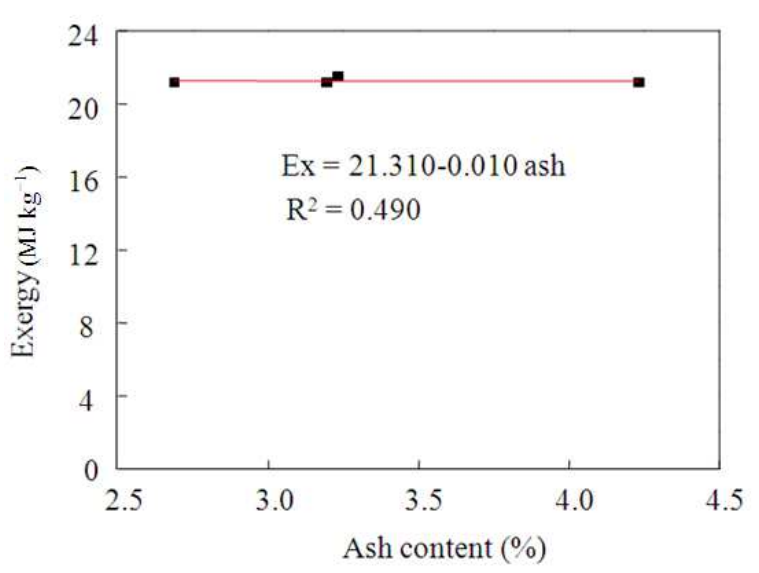

Fig. 4. Relationship between exergy value and ash content

Although $\mathrm{SiO}_{2}$ had the highest weight fractions (up to $40.33 \%$ ), it ranked the seventh in terms of its contribution to the total exergy values of ash. This is due to the fact that the exergy value of $\mathrm{SiO}_{2}(7.9 \mathrm{~kJ}$ $\left.\mathrm{mol}^{-1}\right)$ is the lowest among the exergy values of the ash components (7.9-413.10 $\mathrm{kJ} \mathrm{mol}^{-1}$ ).

The total ash related exergy values were 53.468, $53.819,72.065$ and $117.675 \mathrm{~kJ} \mathrm{~kg}^{-1}$ for the Absolvant, Max, Monopol and Vuka wheat straws, respectively. The Vuka wheat straw had the highest total ash related exergy $\left(117.675 \mathrm{~kJ} \mathrm{~kg}^{-1}\right)$ whereas the Absolvant wheat straw had the lowest total ash related exergy $(53.468 \mathrm{~kJ}$ $\left.\mathrm{kg}^{-1}\right)$. This is mainly due to the ash content as the Vuka wheat straw had the highest ash content (4.23\%) whereas the Absolvant wheat straw had the lowest ash content $(2.69 \%)$.

Song et al. (2012) estimated the exergy of solid and liquid fuels and reported decreases in exergy when the ash content increased. 


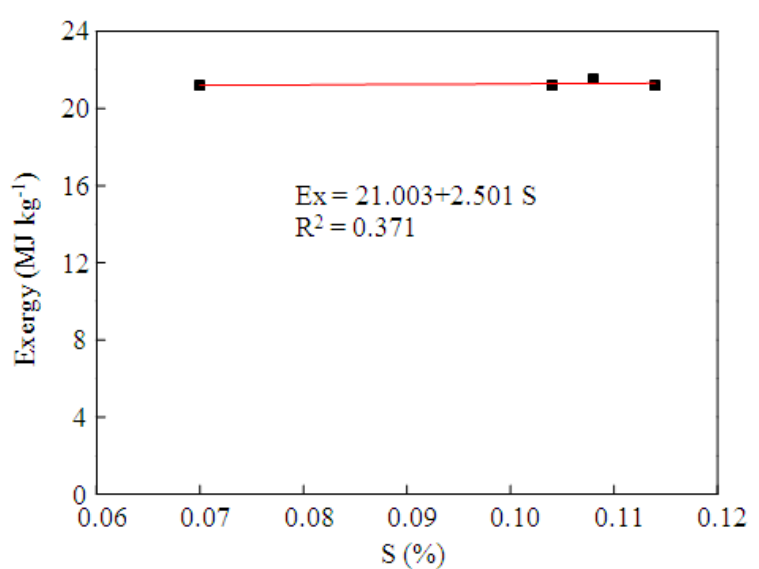

Fig. 5. Relationship between exergy value and $S$

In this study, a negative linear relationship between the exergy value and ash content was observed (Fig. 4). The relationship can be described by the following linear equation $\left(R^{2}=0.490\right)$ :

$$
\mathrm{Ex}=21.310-0.010 \text { Ash } \quad(2.688 \leq \mathrm{Ash} \leq 4.233)
$$

where:

$$
\text { Ash = The ash content }(\%)
$$

The results showed that increasing the ash content from $2.69 \%$ to $4.23 \%(57.25 \%)$ decreased the exergy of wheat straw from $21.503 \mathrm{MJ} \mathrm{kg}^{-1}$ to $21.156 \mathrm{MJ} \mathrm{kg}^{-1}$ (1.61\%). The results indicated that the effect of ash content on the exergy value of wheat straw is very small and can be neglected. Hepbasli (2008) and Szargut et al. (1988) stated that the exergy of ash can usually be neglected because the change in total exergy of fuel due to the change in ash content is very small.

\subsubsection{Effect of $S$}

The $\mathrm{S}$ related exergy values of straws were directly determined by the weight fractions of $\mathrm{S}$. The $\mathrm{S}$ related exergy values were $10.109,6.817,10.458$ and $11.077 \mathrm{~kJ}$ $\mathrm{kg}^{-1}$ for the Absolvant, Max, Monopol and Vuka wheat straws, respectively. The Vuka wheat straw had the highest $\mathrm{S}$ content $(0.114 \%)$ and the highest $\mathrm{S}$ related exergy value $\left(11.077 \mathrm{~kJ} \mathrm{~kg}^{-1}\right)$ whereas the Max wheat straw had the lowest $\mathrm{S}$ content $(0.070 \%)$ and the lowest $\mathrm{S}$ related exergy value $\left(6.817 \mathrm{~kJ} \mathrm{~kg}^{-1}\right)$.

Bilgen et al. (2004) calculated the exergy of coals and reported increases in exergy when the $\mathrm{S}$ content increased. On the other hand, Govin et al. (2000) estimated the exergy of liquid substances and reported decreases in exergy when S content increased.
Table 6. Percentages of moisture, ash and S related exergy.

\begin{tabular}{lcccc}
\hline Wheat & \multicolumn{4}{c}{ Percentage (\%) } \\
\cline { 2 - 5 } straw & Moisture & Ash & $\mathrm{S}$ & Total \\
\hline Absolvant & 1.734 & 0.253 & 0.048 & 2.034 \\
Max & 1.597 & 0.254 & 0.032 & 1.883 \\
Monopol & 1.311 & 0.335 & 0.049 & 1.694 \\
Vuka & 1.604 & 0.556 & 0.052 & 2.212 \\
\hline
\end{tabular}

Table 7. Molecular structure and atomic ratios of wheat straws.

\begin{tabular}{lccccc}
\hline Wheat & Molecular & \multicolumn{3}{c}{ Atomic ratios } & \multirow{2}{*}{$\beta$} \\
\cline { 3 - 5 } straw & structure & $\mathrm{O} / \mathrm{C}$ & $\mathrm{H} / \mathrm{C}$ & $\mathrm{N} / \mathrm{C}$ & \\
\hline Absolvant & $\mathrm{C}_{158} \mathrm{H}_{244} \mathrm{O}_{115} \mathrm{~N}$ & 0.7307 & 1.5457 & 0.0063 & 1.135 \\
Max & $\mathrm{C}_{65} \mathrm{H}_{97} \mathrm{O}_{46} \mathrm{~N}$ & 0.7133 & 1.5013 & 0.0155 & 1.133 \\
Monopol & $\mathrm{C}_{98} \mathrm{H}_{147} \mathrm{O}_{70} \mathrm{~N}$ & 0.7203 & 1.5088 & 0.0103 & 1.134 \\
Vuka & $\mathrm{C}_{45} \mathrm{H}_{60} \mathrm{O}_{34} \mathrm{~N}$ & 0.7537 & 1.3475 & 0.0225 & 1.138 \\
\hline
\end{tabular}

In this study, a positive linear relationship between exergy value and $\mathrm{S}$ content was observed as shown in Fig. 5. The relationship can be described by the following linear equation $\left(\mathrm{R}^{2}=0.371\right)$ :

$\mathrm{Ex}=21.003+2.501 \mathrm{~S}$

$(0.070 \leq \mathrm{S} \leq 0.114)$

where:

$$
\mathrm{S}=\text { The } \mathrm{S} \text { content }(\%)
$$

The results showed that when the $\mathrm{S}$ content increased from $0.070 \%$ to $0.114 \%(62.857 \%)$, the exergy of wheat straws increased from $21.156 \mathrm{MJ} \mathrm{kg}^{-1}$ to $21.503 \mathrm{MJ} \mathrm{kg}^{-1}$ $(1.64 \%)$. The results indicated that the effect of $\mathrm{S}$ on the exergy value seems to be very small and can be neglected.

\subsubsection{Exergy Distribution}

The percentages of moisture related exergy, ash related exergy and S related exergy are shown in Table 6. The percentages of moisture related exergy varied between $1.311 \%$ and $1.734 \%$ (1.734\%, 1.597\%, 1.311\% and $1.604 \%$ for the Absolvant, Max, Monopol and Vuka wheat straws, respectively), indicating that the contribution of moisture content to the exergy of biomass fuels is, therefore, negligible.

The percentages of ash related exergy varied from $0.253 \%$ to $0.556 \%(0.253 \%, 0.254 \%, 0.335 \%$ and $0.556 \%$ for the Absolvant, Max, Monopol and Vuka wheat straws, respectively), indicating that the ash related exergy values were very small and can be neglected.

The $\mathrm{S}$ related exergy value varied from $6.817 \mathrm{~kJ} \mathrm{~kg}^{-1}$ to $11.077 \mathrm{~kJ} \mathrm{~kg}^{-1}(0.048 \%, 0.032 \%, 0.049 \%$ and $0.052 \%$ for the Absolvant, Max, Monopol and Vuka wheat straws, respectively), indicating that the $\mathrm{S}$ related exergy values were very small and can be neglected. 
The total contribution of moisture related exergy, ash related exergy and $\mathrm{S}$ related exergy accounted for only1.694-2.212\% of the total exergy and can be neglected. Similar results were reported by Hepbasli (2008), Szargut et al. (1988), Song et al. (2012) and Bilgen and Kaygusuz (2008).

\subsubsection{The Correlation Factor $(\beta)$}

The effects of $\mathrm{C}, \mathrm{O}, \mathrm{H}$ and $\mathrm{N}$ can be demonstrated by studying the correlation factors. Based on the $\mathrm{C}, \mathrm{O}, \mathrm{H}$ and $\mathrm{N}$ contents, the $\mathrm{C}, \mathrm{H}, \mathrm{O}$ and $\mathrm{N}$ atomic structure was determined for each straw as shown in Table 7. The numbers of $\mathrm{C}, \mathrm{H}$ and $\mathrm{O}$ atoms varied among the various wheat straws. For every atom of $\mathrm{N}$, the wheat straws contained 45-158 atoms of C, 60-244 atoms of $\mathrm{H}$ and 34-115 atoms of $\mathrm{O}$. The Absolvant wheat straw had the highest atoms of $\mathrm{C}$ (158), $\mathrm{H}(244)$ and $\mathrm{O}(115)$ whereas the Vuka wheat straw had the lowest atoms of C (45), $\mathrm{H}$ (60) and $\mathrm{O}$ (34). This did not agree with the LHVs of wheat straws shown in Table $\mathbf{1}$ where the Monopol wheat straw had the highest LHV (18.71 $\mathrm{MJ} \mathrm{kg}^{-1}$ ) whereas the Vuka wheat straw had the lowest LHV (18.29 $\left.\mathrm{MJ} \mathrm{kg}^{-1}\right)$. This also did not agree with the exergy values of wheat straws shown in Fig. 1 where the Monopol wheat straw had the highest exergy value $\left(21.503 \mathrm{MJ} \mathrm{kg}^{-1}\right)$ whereas the Absolvant wheat straw had the lowest exergy value $\left(21.156 \mathrm{MJ} \mathrm{kg}^{-1}\right)$. This is resulted from the fact that the LHV and exergy of a biomass fuel can be affected not only by the data from its elemental analysis but also from its proximal analysis, structural analysis and physical properties (Vargas-Moreno et al., 2012).

The $\mathrm{O} / \mathrm{C}, \mathrm{H} / \mathrm{C}$ and $\mathrm{N} / \mathrm{C}$ atomic ratios were also calculated as shown in Table 7. The $\mathrm{O} / \mathrm{C}, \mathrm{H} / \mathrm{C}$ and N/C atomic ratios varied in the ranges of $0.7133-0.7537$, 1.3475-1.5457 and 0.0063-0.0225 for the Absolvant, Max, Monopol and Vuka wheat straws, respectively. The $\mathrm{O} / \mathrm{C}$ atomic ratios $(0.7133-0.7537)$ were higher than 0.5 . Equation 6 was selected for the determination of the correlation factors (Table 7). The correlation factors were $1.135,1.133,1.134$ and 1.138 for the Absolvant, Max, Monopol and Vuka wheat straws, respectively. Similar results were also reported by various researches. Bilgen et al. (2004) reported correlation factors between the exergy values and HHVs for coals in the range of 1.0587-1.1260. Zhang et al. (2011) reported correlation factors between the exergy values and LHVs for biomass fuels in the range of 1.05-1.19. Nilsson (1997) reported a correlation factor of 1.16 between the exergy value andLHV for a moist straw.

\section{CONCLUSIONS}

The exergy values of the four wheat straws were determined and the effects of moisture content, ash content, S, C, O, H and $\mathrm{N}$ were calculated. The moisture related exergy varied from $281.834 \mathrm{~kJ} \mathrm{~kg}^{-1}$ (Monopol) to $366.766 \mathrm{~kJ} \mathrm{~kg}^{-1}$ (Absolvant), accounting for $1.311-1.734 \%$ of the total exergy of wheat straws. A negative linear relationship between the exergy value and moisture content was observed. The ash related exergy varied from $53.468 \mathrm{~kJ} \mathrm{~kg}^{-1}$ (Absolvant) to $117.675 \mathrm{~kJ} \mathrm{~kg}^{-1}$ (Vuka), accounting for $0.253-0.556 \%$ of the total exergy of wheat straws. A negative linear relationship between the exergy value and ash content was observed. The $\mathrm{S}$ related exergy varied from $6.817 \mathrm{~kJ}$ $\mathrm{kg}^{-1}$ (Max) to $11.077 \mathrm{~kJ} \mathrm{~kg}^{-1}$ (Vuka), accounting for $0.032-0.052 \%$ of the total exergy of wheat straws. A positive linear relationship between the exergy value and $\mathrm{S}$ content was observed. The $\mathrm{O} / \mathrm{C}, \mathrm{H} / \mathrm{C}$ and $\mathrm{N} / \mathrm{C}$ atomic ratios and the correlation factors varied in ranges of $0.7133-0.7537, \quad 1.3475-1.5457, \quad 0.0063-0.0225$ and $1.133-1.138$, respectively. The exergy values of the four wheat straws were between $21.156 \mathrm{MJ} \mathrm{kg}^{-1}$ (Absolvant) and 21.503 $\mathrm{MJ} \mathrm{kg}^{-1}$ (Monopol). They were mainly determined by the correlation factors and the LHVs. A positive linear relationship between the exergy value and LHV was observed. The combined contribution of ash, moisture and $\mathrm{S}$ related exergy to the total exergy was very small (1.694-2.212\%) and can be neglected.

\section{ACKNOWLEDGEMENTS}

The project was funded by National Science and Engineering Council (NSERC) of Canada.

\section{REFERENCES}

Bilgen, S. and K. Kaygusuz, 2008. The calculation of the chemical exergies of coal-based fuels by using the higher heating values. Applied Energy, 85: 776-785. DOI: 10.1016/j.apenergy.2008.02.001

Bilgen, S., K. Kaygusuz and A. Sari, 2004. Second law analysis of various types of coal and woody biomass in Turkey. Energy Sources, 26: 1083-1094. DOI: 10.1080/00908310490494621

Chen, H., F. Wang, C. Zhang, Y. Shi, G. Jin and S. Yuan, 2010. Preparation of nano-silica materials: The concept from wheat straw. J. Non-Crystalline Solids, 356: 2781-2785. DOI: 10.1016/j.jnoncrysol.2010.09.051 
Chen, L., L. Xing and L. Han, 2009. Renewable energy from agro-residues in China: Solid biofuels and biomass briquetting technology. Renew. Sustainable Energy Rev., 13: 2689-2695. DOI: 10.1016/j.rser.2009.06.025

Çöpür, Y., A. Tozluoglu and Ö. Özyürek, 2012. Sodium borohydrate $\left(\mathrm{NaBH}_{4}\right)$ pretreatment for efficient enzymatic saccharification of wheat straw. Bioresource Technol., 107: 258-266. DOI: 10.1016/j.biortech.2011.12.076

Dincer, I., 2002. The role of exergy in energy policy making. Energy Policy, 30: 137-149. DOI: 10.1016/S0301-4215(01)00079-9

Ergüdenler, A. and A.E. Ghaly, 1993. Agglomeration of silica sand in a fluidized bed gasifier operating on wheat straw. Biomass Bioenergy, 4: 135-147. DOI: 10.1016/0961-9534(93)90034-2

FAO, 2011. Rice Market Monitor.

Ghaly, A.E. and A. Al-Taweel, 1990. Physical and thermochemical properties of cereal straws. Energy Sources, 12: 131-145. DOI: 10.1080/00908319008960195

Govin, O.V., V.V. Diky, G.J. Kabo and A.V. Blokhin, 2000. Evaluation of the chemical exergy of fuels and petroleum fractions. J. Thermal Anal. Calorimetry, 62: 123-133. DOI: 10.1023/A:1010166812761

Guo, Q., X. L. Chen and H. F. Liu, 2012. Experimental research on shape and size distribution of biomass particle. Fuel, 94: 551-555. DOI: 10.1016/j.fuel.2011.11.041

Hedjazi, S., O. Kordsachia, R. Patt, A.J. Latibari and U. Tschirner, 2009. Alkaline sulfite-anthraquinone (AS/AQ) pulping of wheat straw and totally chlorine free (TCF) bleaching of pulps. Industrial Crops Products, 29: 27-36. DOI: 10.1016/j.indcrop.2008.03.013

Hepbasli, A., 2008. A key review on exergetic analysis and assessment of renewable energy resources for a sustainable future. Renewable Sustainable Energy Reviews, 12: 593-661. DOI: 10.1016/j.rser.2006.10.001

Hosseini, M., I. Dincer and M.A. Rosen, 2012. Steam and air fed biomass gasification: Comparisons based on energy and exergy. Int. J. Hydrogen Energy, 37: 16446-16452. DOI: 10.1016/j.ijhydene.2012.02.115

Igathinathane, C., J.S. Tumuluru, S. Sokhansanj, X. Bi and C.J. Lim et al., 2010. Simple and inexpensive method of wood pellets macro-porosity measurement. Bioresource Technol., 101: 6528-6537. DOI: 10.1016/j.biortech.2010.03.034
Liang, C., K.C. Das and R.W. McClendon, 2003. The influence of temperature and moisture contents regimes on the aerobic microbial activity of a biosolids composting blend. Bioresource Technol., 86: 131-137. DOI: 1016/S0960-8524(02)00153-0

Lin, W., K. Dam-Johansen and F. Frandsen, 2003. Agglomeration in bio-fuel fired fluidized bed combustors. Chem. Eng. J., 96: 171-185. DOI: 10.1016/j.cej.2003.08.008

Liu, H., Y. Feng, S. Wu and D. Liu, 2009. The role of ash particles in the bed agglomeration during the fluidized bed combustion of rice straw. Bioresource Technol., 100: 6505-6513. DOI: 10.1016/j.biortech.2009.06.098

Lumpkin, T.A., 2011. Wheat-Global Alliance for Improving Food Security and the Livelihoods of the Resource-poor in the Developing World.

Moran, M. J., H. N. Shapiro, D. D. Boettner and M. B. Bailey, 2011. Fundamentals of engineering thermodynamics. 7th Edn., Wiley, Hoboken, ISBN-10: 1118108019, pp: 112.

Natarajan, E., A. Nordin and A. N. Rao, 1998. Overview of combustion and gasification of rice husk in fluidized bed reactors. Biomass Bioenergy, 14: 533-546. DOI: 1016/S0961-9534(97)10060-5

Nilsson, D., 1997. Energy: Exergy and emergy analysis of using straw as fuel in district heating plants. Biomass Bioenergy, 13: 63-73. DOI: 10.1016/S0961-9534(97)00025-1

Petrik, S., Z. Kádár and I. Márová, 2013. Utilization of hydrothermally pretreated wheat straw for production of bioethanol and carotene-enriched biomass. Bioresource Technol., 133: 370-377. DOI: 10.1016/j.biortech.2013.01.151

Pommier, S., D. Chenu, M. Quintard and X. Lefebvre, 2008. Modelling of moisture-dependent aerobic degradation of solid waste. Waste Manage., 28: 1188-1200. DOI: 10.1016/j.wasman.2007.05.002

Ren, Q., C. Zhao, X. Wu, C. Liang and X. Chen et al., 2010. Formation of NOx precursors during wheat straw pyrolysis and gasification with $\mathrm{O}_{2}$ and $\mathrm{CO}_{2}$. Fuel, 89: 1064-1069. DOI: 10.1016/j.fuel.2009.12.001

Rosen, M.A. and C.A. Bulucea, 2009. Using Exergy to Understand and Improve the Efficiency of Electrical Power Technologies. Entropy, 11: 820-835. DOI: 10.3390/e11040820 
Shrivastava, B., P. Nandal, A. Sharma, K.K. Jain and Y.P. Khasa and T.K. Das et al., 2012. Solid state bioconversion of wheat straw into digestible and nutritive ruminant feed by Ganoderma sp. rckk02. Bioresource Technol., 107: 347-351. DOI: 10.1016/j.biortech.2011.12.096

Song, G., J. Xiao, H. Zhao and L. Shen, 2012. A unified correlation for estimating specific chemical exergy of solid and liquid fuels. Energy, 40: 164-173. DOI: 10.1016/j.energy.2012.02.016

Szargut, J., 1980. International progress in second law analysis. Energy, 5: 709-718. DOI: 10.1016/0360-5442(80)90090-0

Szargut, J., D.R. Morris and F.R. Stewart, 1988. Exergy analysis of thermal. Chem. Metallurgical Processes. Edwards Brothers, Inc.

Talebnia, F., D. Karakashev and I. Angelidaki, 2010. Production of bioethanol from wheat straw: An overview on pretreatment: Hydrolysis and fermentation. Bioresource Technol., 101: 4744-4753. DOI: 10.1016/j.biortech.2009.11.080

Tesfa, B., F. Gu, R. Mishra and A.D. Ball, 2013. LHV predication models and LHV effect on the performance of CI engine running with biodiesel blends. Energy Conversion Manage., 71: 217-226. DOI: 10.1016/j.enconman.2013.04.005

Vargas-Moreno, J.M., A.J. Callejón-Ferre, J. Pérez-Alonso and B. Velázquez-Martí, 2012. A review of the mathematical models for predicting the heating value of biomass materials. Renew. Sustainable Energy Reviews, 16: 3065-3083. DOI: 10.1016/j.rser.2012.02.054

Wall, G., 1986. Exergy-a useful concept (3rd edition). Physical Resource Theory Group. Göteborg.
Wang, C., F. Wang, Q. Yang and R. Liang, 2009. Thermogravimetric studies of the behavior of wheat straw with added coal during combustion. Biomass Bioenergy, 33: 50-56. DOI: 10.1016/j.biombioe.2008.04.013

Wen, C., M. Xu, D. Yu, C. Sheng, H. Wu and P. Zhang et al., 2013. $\mathrm{PM}_{10}$ formation during the combustion of $\mathrm{N}_{2}$-char and $\mathrm{CO}_{2}$-char of Chinese coals. Combustion Institute, 34: 2383-2392. DOI: 10.1016/j.proci.2012.07.080

Wild, P.J. D., W.J.J. Huijgen and H.J. Heeres, 2012. Pyrolysis of wheat straw-derived organosolv lignin. J. Analytical and Applied Pyrolysis, 93: 95-103. DOI: 10.1016/j.jaap.2011.10.002

Xie, L., M. Liu, B. Ni, X. Zhang and Y. Wang, 2011. Slow-release nitrogen and boron fertilizer from a functional superabsorbent formulation based on wheat straw and attapulgite. Chem. Eng. J., 167: 342-348. DOI: 10.1016/j.cej.2010.12.082

Zhang, Y., A.E. Ghaly and B. Li, 2012. Physical properties of wheat straw varieties cultivated under different climatic and soil conditions in three continents. Am. J. Eng. Applied Sci., 5: 98-106. DOI: 10.3844/ajeassp.2012.98.106

Zhang, Y., B. Li, H. Li and H. Liu, 2011. Thermodynamic evaluation of biomass gasification with air in autothermal gasifiers. Thermochimica Acta, 519: 65-71. DOI: 10.1016/j.tca.2011.03.005

Zhao, Y., S. Sun, H. Che, Y. Guo and C. Gao, 2012. Characteristics of cyclone gasification of rice husk. Int. J. Hydrogen Energy, 37: 16962-16966. DOI: 10.1016/j.ijhydene.2012.08.093 